\title{
Archaeoseismological analysis of a Late Bronze Age site (Tira del Lienzo) on the Alhama de Murcia Fault, SE Spain
}

\begin{tabular}{|r|l|}
\hline Journal: & Geoarchaeology \\
\hline Manuscript ID: & GEO-14-043.R2 \\
\hline Wiley - Manuscript type: & Research Article \\
\hline Complete List of Authors: & $\begin{array}{l}\text { Ferrater, Marta; Universitat de Barcelona, RISKNAT Group. GEOMODELS. } \\
\text { Departament de Geodinàmica i Geofísica, Facultat de Geologia } \\
\text { Silva, Pablo; Universidad de Salamanca, Dpto. Geología, Escuela } \\
\text { Politécnica Superior de Ávila } \\
\text { Ortuño, Maria; Universitat de Barcelona, RISKNAT Group. GEOMODELS. } \\
\text { Departament de Geodinàmica i Geofísica, Facultat de Geologia } \\
\text { Rodríguez-Pascua, Miguel; Instituto Geológico y Minero de España (IGME), } \\
\text { Masana, Eulàlia; Universitat de Barcelona, RISKNAT Group. GEOMODELS. } \\
\text { Departament de Geodinàmica i Geofísica, Facultat de Geologia }\end{array}$ \\
\hline Keywords: & $\begin{array}{l}\text { Archaeoseismology, Earthquake Archaeological Effects (EAEs), Bronze Age, } \\
\text { Alhama de Murcia Fault, Betic Cordillera }\end{array}$ \\
\hline & \\
\hline
\end{tabular}




\title{
Archaeoseismological analysis of a Late Bronze Age site (Tira del
}

\section{Lienzo) on the Alhama de Murcia Fault, SE Spain}

\author{
Marta Ferrater ${ }^{1}$, Pablo G. Silva ${ }^{2}$, Maria Ortuño, Miguel Ángel Rodríguez-Pascua ${ }^{3}$, \\ Eulàlia Masana ${ }^{1}$
}

${ }^{1}$ RISKNAT Group. GEOMODELS. Departament de Geodinàmica i Geofísica, Facultat de Geologia, Universitat de Barcelona, c/ Martí i Franquès s/n, 08028 Barcelona, España (marta.ferrater@ub.edu)

${ }^{2}$ Dpto. Geología, Universidad de Salamanca Escuela Politécnica Superior de Ávila, Ávila, Spain

${ }^{3}$ Instituto Geológico y Minero de España (IGME), c/ Ríos Rosas, 23, Madrid, Spain

\begin{abstract}
An archaeoseismological study of Tira del Lienzo (Totana, Spain) was undertaken. The settlement belongs to the Argar archaeological group (2,200-1,550 cal BC; Bronze Age). The site is located on the trace of the reverse left-lateral Alhama de Murcia fault (AMF), which was responsible for the 5.1 Mw 2011 Lorca earthquake. The constructive typology of the site consists of free-mortar irregular natural boulders (dry-set masonry) and differs from earlier archaeoseismological sites built on regular masonry constructions in the Betic Cordillera. Four Earthquake Archaeological Effects (EAE) were identified: 1) an apparent surface rupture (c. $18 \mathrm{~cm}$ left-lateral offset), 2) the differential coseismic uplift of several centimetres affecting the main building of the settlement, 3) the widespread development of fractures on the ground surface (ground cracks) in a NE-SW direction consistent with the kinematics of the AMF, and 4) fractures in boulders that constitute the remains of the dry stone walls at the site. Structural analysis of the two types of fractures reveals two nearly orthogonal sets (NE-SW and NW-SE), matching the strike-slip kinematics of the AMF in the zone. Archaeoseismic evidence and related radiocarbon dates of the different building phases of the Bronze Age site indicate the probable occurrence of at least one strong seismic event (6.3 - 6.5 Mw; IX ESI-07) around 1,550 cal BC, or soon after, triggering the destruction and probably the eventual abandonment of the site. The study recovers an ancient lost earthquake from the Bronze Age and reports the first archeoseismological evidence of surface rupture in the Iberian Peninsula. It also provides first numerical data in the Totana-Alhama segment of the AMF based on the recorded archaeoseismic displacements. This data enabled us to characterize the
\end{abstract}


related slip-rates $(0.05 \mathrm{~mm} / \mathrm{yr})$ of application to define the seismic potential of the analysed fault segment of the AMF, which was poorly defined by previous seismic and geological data.

Key words: Archaeoseismology, Earthquake Archaeological Effects (EAE), Bronze Age, Alhama de Murcia Fault, Betic Cordillera, SE Spain.

\section{INTRODUCTION}

Although the oldest archaeoseismological evidence in the world is located in northern Iraq (Middle Palaeolithic, c. 50,000 years old), archaeoseismological studies usually date from the Bronze Age (c. 1700 BC; Nur \& Burgess, 2008). From the archaeoseismological perspective, the oldest archaeological sites in the Iberian Peninsula are Baelo Claudia in Cadiz (Silva et al., 2005; 2009) and Ilunum in Albacete (Tolmo de Minateda; Rodríguez-Pascua et al., 2010; 2013a). Both these sites are located in the Betic Cordillera and were affected by repeated earthquakes between the $1^{\text {st }}$ and $4^{\text {th }}$ centuries AD (Silva \& Rodriguez-Pascua, 2014). These Roman sites show abundant archaeoseismic evidence of seismic ground shaking. Multiple Earthquake Archaeological Effects (EAE) from the classification of Rodríguez-Pascua et al. (2011) were identified, most of them related with permanent deformations of the fabric of buildings and pavements and notable oriented damage.

The Tira del Lienzo site, from the Bronze Age, constitutes the oldest archaeoseismological record in Spain, as preliminary evidence of fault offset in the archaeological remains suggest (Ferrater et al., 2013). In this study we follow the guidelines of the classification of "Earthquake Archaeological Effects" (EAE) proposed by Rodríguez-Pascua et al. (2011) in order to characterise the site 
archaeoseismologically. However, the type of dry-set masonry (irregular boulders) construction style used at the site is not specifically considered in the EAE classification of these authors, and thereby new types of EAE are described in this paper for consideration in future updates of the classification. The described EAE come from the recognition of a suspect wall offset in a microtopographic map of the archaeological site and preliminary field research (Ferrater, 2013; Ferrater et al. 2013). The detailed map, published for the first time in this paper, was provided by the team from the Universitat Autònoma de Barcelona (UAB) in charge of archaeological research at the La Bastida de Totana site (La Bastida Project). This site constitutes the largest fortified metropolis of the Late Bronze Age in the western Mediterranean, especially during its final occupation period (1900 -1550 cal BC; Lull et al., 2014), and it is informally known in the archaeological community as the Little Western Troy.

Tira del Lienzo is a settlement at the top of a small hill forming part of the La Bastida metropolis (Lull et al., 2011a) and is located on the Alhama de Murcia fault (AMF) zone. In detail, the site is founded on a $35 \mathrm{~m}$ high elongated pressure ridge developed on the trace of the Totana-Alhama segment of the AMF, which has not been subject to previous palaeoseismic analyses. Although the AMF is one of the more active faults in the Iberian Peninsula, and was responsible for the damaging 5.1 Mw 2011 Lorca earthquake (López-Comino et al., 2012), its historical earthquake record (I max = VIII EMS-98) does not go beyond the $14^{\text {th }}$ century. Owing to the poor pre-instrumental record for this fault, several palaeoseismic studies have been carried out to assess LatePleistocene to Late Holocene surface faulting events in the adjacent Lorca-Totana segment (Silva et al., 1997; Martínez-Díaz, 1998; Martínez-Díaz et al., 2001; MartínezDíaz et al., 2003; Masana et al., 2004), and also in the southern horse tail termination of 
the fault (Ortuño et al., 2012). An archaeoseismological study, in a location known to be on-fault location, would be able to detect ancient earthquakes, thereby allowing us to improve the existing pre-instrumental record.

\section{SEISMOTECTONIC FRAMEWORK OF THE ZONE: THE ALHAMA DE MURCIA FAULT ZONE (AMF)}

The site under study is located in the AMF zone, which controls the recent development of the landscape and the seismic activity in the area. The AMF is a N45 $-65^{\circ} \mathrm{E}$ leftlateral strike-slip fault with a reverse component, consistent with NW-SE convergence between the Eurasian and the African plates (Silva, 1994; Martínez-Díaz, 1998). This fault zone constitutes the key element of one of the main crustal-scale active tectonic structures of the Eastern Betic Cordillera, the Eastern Betic Shear Zone (EBSZ; Silva et al., 1993; Martínez-Díaz et al., 2001, 2012; Masana et al., 2004). The Totana-Alhama segment is the smallest central segment of the fault $(11 \mathrm{~km}$; Figure 1$)$. Together with the adjacent Lorca-Totana segment this segment displays fault branching, with a northern branch controlling the $\mathrm{N} 45^{\circ} \mathrm{E}$ Espuña range composed of metamorphic Betic rocks, and a $\mathrm{N} 65^{\circ} \mathrm{E}$ southern branch affecting Upper Neogene to Quaternary sediments (Silva et al., 2008). Fault branching promoted the generation of a set of triangular strike-slip basins between the main faulted mountain front and the southern fault branches. These basins are filled by thick series of Early to Middle Pleistocene alluvial fan deposits (Silva et al., 2003). Crusted Middle Pleistocene alluvial fan surfaces are distally offset and uplifted by the younger activity of the southern branch and incorporated into the pressure ridges developed in this area (Silva, 1994; Silva et al., 1992). Along this southern branch, a set of restraining strike-slip fault landforms such as pressure ridges, 
spur ridges and sinestrally deflected stream channels are assembled on intervening $\mathrm{N} 65^{\circ} \mathrm{E}$ linear tectonic landforms separating the main mountain front from the Guadalentin Tectonic Depression (Figure 1 and 2A).

Instrumental records of earthquakes indicate that $90 \%$ of the seismicity is shallow, that is less than $20 \mathrm{~km}$ in depth (Martínez-Díaz, 1998). The most significant historical earthquakes (VIII EMS) in the AMF are those that occurred in AD 1579, 1674 and 1818 at Lorca (Lorca-Totana fault segment). The only event reported in the Totana-Alhama segment, the subject of this study, is the AD 1907 event at Totana that reached an intensity of VII EMS (IGN, 2012). The strongest instrumentally recorded event along the fault zone occurred in Lorca on 11 May 2011 (Mw 5.1) and had VII EMS intensity (López-Comino et al., 2012). None of these historical or instrumental seismic events triggered surface faulting (Silva et al., 1997; Martínez-Díaz et al., 2012). However, the first palaeoseismic studies of the zone found robust evidence of Late Pleistocene to Holocene surface faulting along the AMF zone (Silva, 1994; Silva et al., 1997; Martínez-Díaz, 1998). Other palaeoseismic studies based on fault-trenching analyses on this fault characterised a number of surface-faulting palaeoearthquakes, with maximum magnitude values in the range of Mw 6.1-7.0 (Martínez-Díaz et al., 2001, Masana et al. 2004; Ortuño et al., 2012). These studies recorded a minimum of six palaeoseismic events during the last 274-174 kyr. Initial fault-trenching analyses (Martínez-Díaz et al., 2003) estimated average vertical slip-rates of $0.21 \mathrm{~mm} / \mathrm{yr}$ for the last $130 \mathrm{Kyr}$. However, further more systematic palaeoseismic analyses and recent regional reviews (Masana et al., 2004; Ortuño et al., 2012; Martínez-Díaz et al., 2012) report maximum vertical slip-rates of $0.35 \mathrm{~mm} / \mathrm{yr}$, maximum lateral slip-rates of $0.53 \mathrm{~mm} / \mathrm{yr}$ and maximum net slip-rates of $0.66 \mathrm{~mm} / \mathrm{yr}$. Recent geodetic studies indicate that the 
ongoing horizontal slip-rates for the last 15 years are $0.70 \pm 0.2 \mathrm{~mm} / \mathrm{yr}$, in the range of the maximum rates obtained by paleoseismic analyses (CuaTeNeo GPS network; Echeverria et al., 2013). DinSar and GPS analyses after the 2011 Lorca earthquake (Mw 5.1) revealed coseismic vertical deformation of about 3-4 $\mathrm{cm}$ along the trace of the AMF north of Lorca (Frontera et al., 2012).

These studies were, however, mainly focused on the Lorca-Totana segment, rather than on the smaller Totana-Alhama segment in which our site is located. This segment only records the aforementioned VII EMS AD 1907 event and few V-IV EMS earthquakes occurred during the $19^{\text {th }}$ and $20^{\text {th }}$ centuries. The seismic potential of this fault segment is determined on the basis of theoretical approaches, suggesting a capacity to generate 5.9 - 6.5 Mw events (Martínez-Díaz et al., 2012).

\section{TIRA DEL LIENZO: GEOLOGICAL AND ARCHAEOLOGICAL SETTING}

\section{Geology and Geomorphology}

The archaeological site is located on strongly cemented, fairly deformed and uplifted Quaternary alluvial fan deposits on the top of an elongated pressure ridge developed on the trace of the southern branch of the AMF (Figure 2A). In this zone the fault has an overall ENE-WSW trend and mainly left-lateral to inverse kinematics, resulting in the development of well-preserved high pressure ridges, several hundred metres long and 12-7 m high (Figure 2A; Silva, 1994; Silva et al., 1993). The pressure ridge on which the site is located is currently affected by quarry works (Figure 2B) that display nearly the whole fault zone under the site (c. $100 \mathrm{~m}$ wide). The fault zone is constituted by 
faulted and strongly folded marls dipping SE and mylonitic gypsums of the Miocene (Figure 2B). At the top there are uplifted alluvial fan deposits.

Uplifted Quaternary alluvial fan deposits beneath the archaeological remains display thick (1-2 m) calcrete soil profiles, which on the basis of regional studies on alluvial fan sequences and calcrete development (Alonso-Zarza et al., 1998; Silva, 2014) date from c. 780 kyr (Early-Middle Pleistocene transition) to c. $380 \mathrm{kyr}$ (Silva, 2014). Also of note, alluvial fan deposits record an accumulated uplift of c. 8-7 $\mathrm{m}$ and the adjacent Sisquilla rambla-creek (60 $\mathrm{m}$ from the site) shows a significant left-lateral displacement of 23-20 m (Figure 2A) from the last c. 350 kyr (Middle Pleistocene; Silva, 1994).

\section{Archaeology and Geoarchaeology}

Tira del Lienzo is a small archaeological Early Bronze Age site, belonging to the socalled 'Argaric Culture' located near Totana (Murcia, SE Spain). This ancient culture prospered between 2,200 and 1,550 cal BC in the south-eastern sector of the Iberian Peninsula comprising the present provinces of Almeria, Granada and Murcia (Lull, 1983; Lull et al., 2011a; Lull et al., 2014). According to these authors, the site under study is related to one of the largest metropolises of Early Bronze Age culture in SE Spain (La Bastida de Totana), located about $7 \mathrm{~km} \mathrm{SW}$ from the site (Figure 1). The first human occupation recorded at the La Bastida site dates from 2,200 cal BC and it was finally abandoned between 1,600 and 1,550 cal BC (Lull et al., 2011a; Lull et al., 2014). However, Tira del Lienzo was occupied from 2,050 to 1,600/1,550 cal BC. There are two main phases of occupation and building development at this site, the first in 2,050$1,900 \mathrm{cal} \mathrm{BC}$ and the second in 1,900-1,550 cal BC, bracketed by the radiocarbon ages reported by the La Bastida archaeological project (e.g. Lull et al., 2011a; Delgado- 
Raack et al., 2014). Our study is focused on the second phase of occupation $(1,900-$ 1,550 cal BC), where the archaeoseismological evidence is preserved (Figure 3). Archaeological data indicate that this site constituted a small settlement used for administration and management of agricultural production, linked to La Bastida (Delgado-Raack et al., 2014).

During the second phase (1,900-1,550 cal BC), the structure of the settlement consisted of a minimum of seven rectangular or trapezoidal houses/enclosures (15 to $27 \mathrm{~m}^{2}$ each) around a larger rectangular central building (c. $90 \mathrm{~m}^{2}$ ) oriented NE-SW (Figure 3; Delgado-Raack et al., 2014). The dimensions of the remains are about $750 \mathrm{~m}^{2}$ surrounded by a wall about $1 \mathrm{~m}$ to $1.20 \mathrm{~m}$ wide. The main architectural features of the buildings consist of rectangular rooms with dry stone walls $50-60 \mathrm{~cm}$ wide made up of boulders of decimetric size (Figure 4; Lull et al., 2011b). The rocky ground of the site is constituted by indurated calcrete soils developed on top of the Middle Pleistocene alluvial fan deposits. At present, the remains display the lower three to four rows $(<1 \mathrm{~m}$ high) of the original dry-set masonry walls, in which the apparent archaeoseismic damage is recorded. Archaeological excavations started in the year 2010 when the settlement was completely buried by numerous stone-blocks, a consequence of the collapse and downfall of the original dry stone walls (González Guerao, 2005).

\section{ARCHAEOSEISMOLOGY OF THE SITE}

The archaeoseismological analysis of the site is focused on 1) the inventory of Earthquakes Archaeological Effects (EAE) recorded at the site on the basis of the classification of Rodríguez-Pascua et al. (2011), and on 2) structural analysis of the observed fractures and the AMF zone. 


\section{Earthquake Archaeological Effects (EAE)}

Four types of EAE were recorded at the site (Figure 5): (a) ground fractures (Figures 3 and 4A), (b) broken wall-boulders (Figure 4B), (c) offset/folded walls (Figures 3 and 5), and (d) seismic uplift/subsidence (Figure 3). The first two of these EAE ( $a$ and $b$ ) are not included in the classification of Rodriguez-Pascua et al. (2011) because the constructive type (dry-set masonry) and building material (boulders) featured in the site were not considered by these authors. These two new EAE have been described by Ferrater (2013) and Ferrater et al. (2013). These authors acknowledge that these two EAE have their respective equivalents in the classification of Rodríguez-Pascua et al. (2011) albeit affecting other constructive types and materials. Rocky ground fractures (a) in the natural floor (indurate calcrete surface) correspond to the "regular and irregular fractures and folds in pavements" (Figure 5) of Rodríguez-Pascua et al. (2011). On the other hand, the broken boulders (b) recorded in the dry stone walls at this site are equivalent to the "penetrative fractures in masonry blocks" of the aforementioned authors (Figure 5).

Ground fractures (Figures 3, 4 and 5). The rocky surface where the Tira del Lienzo archaeological remains are located can be considered an almost rigid element owing to the surface calcrete cementation of the alluvial deposits (Figure 2B). This hardened surface would behave as any thick (c. $1 \mathrm{~m}$ ) anthropic cemented pavement. In the event of ground shaking, this surface undergoes similar deformations (mainly cracking) to those listed for man-made pavements in the EAE classification of Rodríguez-Pascua et al. (2011) (Figure 5) and in the ESI-07 macroseismic scale (Michetti et al., 2007). The surface calcrete horizon overlays the 2-3 m thick weakly cemented alluvial materials 
outcropping at the top of the pressure ridge (see Figure 2B). These alluvial deposits, with soil-like geotechnical properties, constitute a relatively soft layer between the more competent underlying rocks of the fault zone and the overlying calcrete horizon. Ground cracks display NE-SW dominant orientations. Some of them exceed 4-5 $\mathrm{m}$ in length and have a millimetric width at indoor locations (Figure 4A). Cracks are arranged in a fracture system that crosses the entire archaeological site parallel to the AMF zone (Figure 4). This fracture system mainly affects the central building (H1) and House 10 (H10; Figure 3), extending outdoors along the whole hilltop of the site (c. $40 \mathrm{~m}$ length). These ground cracks are decametric in length and some of them are a few $\mathrm{cm}$ to $\mathrm{mm}$ wide, a large number of them showing partial or complete thin calcrete coatings. This indicates that ground cracking was a recurrent process in this hilltop site before, and probably after, its occupation during the Early Bronze Age. The largest ground cracks affecting the site appear as open cracks, in some cases $1-1.5 \mathrm{~cm}$ wide, and they are currently filled with soil. Figure 3 shows that the main indoor fracture system is closely associated with most of the other EAE recorded in this study.

Broken wall-boulders. Individual blocks of varying dimensions are vertically cracked (Figure 4B) preferentially in the NW-SE walls (88\%). These walls are orthogonal to the ground fracture system and in some cases (30\%) the broken boulders are spatially related to rocky ground cracks (Figure 3). As regards ground failure, vertical propagation of these ground fractures towards and in the walls is likely to have occurred. However, these fractures are not clearly recorded after the works that repaired most of the stone walls. The original mortar-free construction of the dry stone walls probably contributed to the vertical inter-block propagation of the fractures, although intra-block cracking occurred in some cases. An intricate arrangement of inter- to intra- 
block fracture propagation within the dry stone wall is feasible. This was probably facilitated by the jagged assemblage of the rows of rough blocks in the walls, resulting in irregular and discontinuous vertical fracture propagation unlike the almost-linear propagation of penetrative fractures in regular masonry blocks described in RodríguezPascua et al. (2011). In fact, dry stone walls appear to be more resistant to earthquakes than are walls constructed with mortar (which serves as clamp), and thus they could undergo inter-block sliding and resettle without collapsing (Senthivel et al., 2006). Analytical models suggest that inter-block propagation of the fractures is the main deformation control in dry stone walls, although intra-block cracking or crushing can occur in the lower third of the wall, especially in cases of ground failure (Senthivel et al., 2006; Colas et al., 2013). According to these authors, the intra-block fracture system opens progressively upwards, causing extensive damage to the upper halves of the walls and leading to their collapse. Fracture generation has also been attributed to other causes such as thermal contrast caused by fire. In such cases, the fractures would be parallel to the wall.

Offset and folded walls. This is the most striking archaeoseismological feature recorded at Tira del Lienzo. Folding and disruption of dry stone walls are always recorded in the NW-SE walls and are in direct relationship with the two EAE described above, especially with the ground fractures (Figure 3). As shown in Figure 3, wall folding was recorded in two walls (W43 and W29) of the main building (House 1), in the southern wall (W46) of House 10 and in the northern wall of the site (W5). The most significant relationship between a folded wall and a ground crack is well-preserved in the ancient doorway of House 10 (W46; Figure 3). In this zone, one of the main ground fractures of millimetric width propagates NE-SW indoors and outdoors affecting the entire building 
over at least c. $10 \mathrm{~m}$ and reaching the northern wall of the site. The ground rupture coincides with an apparent differential uplift of several centimetres $(5-8 \mathrm{~cm})$ between the eastern (up) and western (down) portions of the house. At the ancient doorway, these two portions of the building record a visible left-lateral offset of $18 \mathrm{~cm}$ (Figure 6) that is consistent with the kinematics of the AMF under the site. In fact, NW-SE oriented walls (orthogonal to the overall NE-SW fault strike) constitute linear markers that record the strike-slip. In detail, the NW segment of the disrupted wall W46 displays a left-lateral drag bend-like deformation (Fig 6A and 6B). The recorded wall offset can be considered a reliable feature for surface rupture related to the fracture system crossing the archaeological site. As shown in Figure 3, the mapping of ground fractures records similar left-lateral anomalies in the other folded walls. All these fractures are related to the main NE-SW fracture system affecting House 10 (W46), House 1 (W29) and the northern wall (W5). To the SE, the zone is not excavated, and it is not possible to follow the fractures. It is therefore reasonable to consider this NE-SW fracture system as evidence of the left-lateral surface deformation and of the centimetric differential uplift along the trace of the AMF. The coincidence of surface faulting with the ancient doorway of House 10 allows measurement of the offset $(18 \mathrm{~cm})$ since in the other cases the walls are only folded.

Wall folding above the trace of the NE-SW fracture system was probably facilitated by the relatively inter-block free sliding favoured by the dry stone masonry style and the absence of wall foundations (Senthivel et al., 2006). All cases of wall folding are linked to the occurrence of broken wall-boulders (Figure 3), which is interpreted as occasional intra-block cracking in the lower portions of the wall due to ground failure, as described in laboratory analogues (Colas et al., 2013; see Broken wall-boulders section). In this 
case, inter- and intra-block sliding linked to the process of wall bending will be the result of the upward propagation into the buildings of the centimetric left-lateral displacement along the NE-SW ground fracture system. As discussed in the Broken wall-boulders section, this mechanism of deformation will cause the destruction of the upper portions of the walls and buildings (Colas et al., 2013; Senthivel et al., 2006).

Seismic uplift/subsidence. The site displays centimetric ground uplift related to the ground rupture in H10 (Figures 3 and 6). As stated above, this uplift coincides with the offset wall and with the broken boulders in some walls. The magnitude of the vertical offset ranges between five and eight centimetres and uplifts the SE portion of the house (H10).

\section{Structural analysis of EAEs}

The structural analysis was performed with rocky ground fractures and broken boulders, using 60 ground fracture data and 28 boulder fracture data. The results indicate the occurrence of two consistent NE-SW and NW-SE orientations of fracturing in both data sets with a NE-SW dominant orientation (Figure 4). The dominant orientation coincides with the AMF orientation in the fault zone outcrop located beneath the site (see Figure 2B). Therefore, the consistent fault and fracture orientations (including the main surface rupture recording left-lateral offset in House 10; W46) strongly suggest that the generation of the analysed fractures was controlled by fault activity. The ruin of the buildings due to other causes would, by contrast, have produced randomly oriented wall displacements and fractures in dry stone wall boulders, not necessarily consistent with the ground fractures affecting the site. Coseismic left-lateral displacement and differential uplift probably triggered on-fault ground failure. As a result, the upper 
halves of the walls were destroyed whereas their lower halves underwent fracturing. This has been corroborated by analytical analyses of dry-set masonry constructions (Senthivel et al., 2006; Colas et al., 2013).

\section{DISCUSSION: PALAEOSEISMIC ANALYSIS}

On the basis of 1) the left-lateral displacement recorded by offset wall 46 in House 10 $(18 \mathrm{~cm})$ and on 2) the apparent surface uplift $(5-8 \mathrm{~cm})$ related to the NE-SE fracture system affecting the site (Figure 3), it is possible to obtain empirical approximations of the size of the suspected palaeoseismic event and slip rates of the AMF in this fault segment.

Application of the empirical magnitude-displacement relationship for strike-slip faults (Wells \& Coppersmith, 1994) to the ground rupture data (which considers both the 18 $\mathrm{cm}$ of lateral displacement and $8 \mathrm{~cm}$ of maximum uplift) would imply the occurrence of a $6.4 \pm 0.1 \mathrm{Mw}$ earthquake. The magnitude of this event is consistent with the theoretical seismic potential of the Totana-Alhama fault segment $(5.9-6.5 \mathrm{Mw}$; Martínez-Díaz et al., 2012). The above relationship is at the limit of its magnitude range of application; however, it has been extensively used in all the previous palaeoseismic analyses developed in the AMF and is the most reliable tool for comparing calculated magnitudes along the whole fault zone (e.g. Martínez-Díaz et al., 2012). The application of other existing empirical earthquake scaling relationships (e.g. Stirling et al., 2002; Wesnousky, 2008; Stirling et al., 2013) to the site yield similar magnitude values between 5.7 Mw and 6.5 Mw. Surface faulting is rare for magnitudes smaller than 6.5 $\mathrm{Mw}$, and the population of earthquakes used in all the mentioned relationships 
(including Wells \& Coppersmith, 1994) is scarce. This fact results in large uncertainties and accumulated errors that decrease for earthquakes above $6.5 \mathrm{Mw}$ with metric-scale displacements. Another reason for using Wells \& Coppersmith (1994) relationships is that the other empirical earthquake scaling equations do not directly relate magnitude and displacement (Stirling et al., 2002; Wesnousky, 2008; Stirling et al., 2013).

Application of the ESI-07 intensity scale to the surface deformation data implies the occurrence of a palaeoseismic event of IX ESI-07 intensity. This scale takes into account the surface faulting for this minimum intensity value in non-volcanic areas, which results in ground ruptures over a few kilometres with offsets of several centimetres and coseismic uplift of only few centimetres, such as those recorded in the studied site (Michetti et al., 2007). Regarding probable EMS-98 intensity, based on building damage, Karabacak et al. (2013) developed a comparative scheme for EMS-98 (Grünthal, 1998) and ESI-07 (Michetti et al., 2007) intensities recorded in different archaeological sites in the Mediterranean and Europe. In all cases this resulted in bracketed intensity values between VIII and X EMS-98. The work of Karabacak et al. (2013) provides a case of left-lateral surface faulting (c. $20 \mathrm{~cm}$ ) affecting the walls and pavement of the Stadium of the ancient Roman city of Kirbyra (Turkey), reporting an intensity of VIII-IX EMS-98.

In the case of Tira del Lienzo, due to its constructive style, ground shaking of intensity VIII would be sufficient to promote the destruction of the Bronze Age buildings (Rodríguez-Pascua et al., 2013b). Additionally, analytical models of deformation for this constructive style (Senthivel et al., 2006; Colas et al., 2013) indicate that, apart from ground shaking, ground failure in this constructive style triggers the opening of 
large inter-block fractures in the upper halves of the walls and their subsequent destruction. Furthermore, given the hilltop position of the site (narrow pressure ridge), a topographic amplification of seismic shaking is expected. According to the ESI-07 macroseismic scale (Michetti et al., 2007), the record of ground left-lateral displacement of $18 \mathrm{~cm}$ at Tira del Lienzo strongly suggests a maximum intensity of IX (destructive event).

The palaeoseismic analysis of lateral-slip data $(18 \mathrm{~cm})$ results in a fault slip-rate of $0.046 \mathrm{~mm} / \mathrm{yr}$ for the last 3,914 years. Moreover, the striae pitch orientations measured on the fault plane beneath the archaeological site $\left(10^{\circ}-45\right.$; Figures $2 \mathrm{~B}$ and 4$)$ allow us to estimate net lateral slip-rates between $0.024 \mathrm{~mm} / \mathrm{yr}$ and $0.039 \mathrm{~mm} / \mathrm{yr}$. These values are smaller than those reported by earlier palaeoseismic research in the adjacent segment of the AMF (Lorca-Totana; c. 23 km length, Martínez-Díaz et al., 2012), which attained maximum net slip-rate values of c. $0.66 \mathrm{~mm} / \mathrm{yr}$. Our values are, however, consistent with the theoretical seismic potential of the Totana-Alhama fault segment (c. $11 \mathrm{~km}$ length; Martínez-Díaz et al., 2012). Although we assume that ground displacements occurred during a single Bronze Age seismic event in a location known to be on-fault, calculated slip-rates are significant for further seismic hazard analyses. In this sense, this study provides the first slip-rate data based on field analysis for this fault segment, following the preliminary estimations of Ferrater et al., (2013).

\section{GEOARCHAEOLOGICAL APPROACH TO ARCHAEOSEISMIC DAMAGE}

Given the 1) generic magnitude (c. $6.4 \mathrm{Mw}$ ) and maximum intensity (IX) value resulting from the paleoseismic analysis, and 2) the dry-set masonry constructive style 
of the site, the occurrence of an event $\geq$ VIII EMS-98 would have triggered the near destruction of Tira del Lienzo (Senthivel et al., 2006; Rodríguez-Pascua et al., 2013b).

Taking into account the two building phases of construction at the archaeological site (2,050-1,900 and 1,900-1,550 cal BC), the event could have occurred after the construction of the buildings (1,900 cal BC), although most likely it was around or soon after 1,550 cal BC (c. 3,550 years ago). The event could have triggered the eventual abandonment of the site since there is no reconstruction or occupation evidence after this date (Delgado-Raack et al., 2014). Neither, however, is there any evidence to suggest that the settlement was abandoned as a result of an earthquake. The hypothesised date coincides with the decline of Bronze Age populations in the area and the depopulation of the La Bastida metropolis (Lull et al., 2014). Apart from the earthquake, other causes, such as social revolts or social shifting in response to unsustainable agricultural practices, are considered by the La Bastida Project (Lull, Mico, Rihuete, Risch, pers. comm. 2013) as potential explanations for the abandonment of Tira del Lienzo.

Thus, the final abandonment of the La Bastida and Tira del Lienzo sites almost coincide at 1,600/1,550 BC (c. $3.600-3,550 \mathrm{BP}$ ) (Lull et al., 2014), and this is consistent with significant palaeoenvironmental changes in the zone, resulting in a notable depopulation around the Guadalentin Depression (Calmel-Avila, 2002). Geoarchaeological analyses strongly suggest that around 3,500 BP, tectonic activity of the El Romeral rock-bar fault (Librilla) led to generalised fluvial dissection within the Guadalentin Depression upstream of Librilla (Silva et al., 2008; Calmel-Avila et al., 2009). The headward fluvial incision between Librilla and Totana triggered the fragmentation and partial 
disappearance of the palustrine environments, and this brought about the Late Bronze Age depopulation of the zone (Silva et al., 2008; Calmel-Avila et al., 2009). The El Romeral rock-bar fault is a mainly reverse blind $\mathrm{N} 65-70^{\circ} \mathrm{E}$ fault considered by some authors (Silva, 1994; Martínez Díaz, 1998) to be the prolongation of the Totana-Alhama fault segment beneath the sedimentary filling of the Guadalentin Depression. This fault only crops out at El Romeral (Librilla; Figure 1) in the Guadalentin rambla valley, and provides palaeoseismic evidence (sediment perturbation) after 3,885 $\pm 60 \mathrm{BP}$ (CalmelÁvila, 2002).

Whatever the case, at least one earthquake occurred during or soon after the second phase of occupation at Tira del Lienzo (1,900 - 1,550 cal BC; figure 7). The preferred age is around or shortly after the eventual abandonment of the site in 1,550 cal BC, since the presence of broken boulders in the walls is consistent with a structure that is unaffected by the passage of time (Senthivel et al., 2006). The seismic event would have destroyed the upper halves of the walls (Senthivel et al., 2006; Colas et al., 2013) and would have triggered the abandonment of the site if it had occurred during occupation; the archaeological remains would, otherwise, present another phase of reconstruction.

Figure 7 shows that an event within this time frame is consonant with 1) the event dated by fault trenching in the Lorca-Totana segment of the AMF dated at 1760-830 cal BC (Masana et al., 2004), and with 2) the event that caused sediment perturbation in El Romeral (Calmel-Avila, 2002). We do not rule out the possibility that the archaeoseismic damage reported in this study was a consequence of the rupture of more than one segment of the AMF, as illustrated in Table 1. An event affecting both the Lorca-Totana and Totana-Alhama segments can be considered because the magnitude 
obtained by Masana et al. (2004) is within the range of the hypothetical rupture of both segments $(\mathrm{Mw}=6.9 \pm 0.2$; table 1$)$. However, the resulting magnitudes for the rupture of more than one segment of the AMF are higher than the magnitude evaluated from the EAE at Tira del Lienzo, such that a Late Bronze Age seismic period in the central sector of the AMF fault can also be considered. In fact, although the decline of the Bronze Age population in the zone is still not well understood (Lull et al., 2014), some authors (Calmel-Ávila et al, 2009; Silva et al., 2008) point to the occurrence of tectonically induced fragmentation of palustrine zones in the central sector of the Guadalentin Depression upstream of El Romeral rock-bar fault at Librilla. In this scenario, the occurrence of moderate-strong seismic events in the zone would enhance the decline of civilization in the area. In fact, following the Bronze Age decline in c. 1,550 BC, the next urban settlements in the area did not appear until Phoenician times, around the $6^{\text {th }}$ century BC (c. $500 \mathrm{BC})$.

\section{CONCLUSIONS}

Tira del Lienzo, a Bronze Age site, is located in the Totana-Alhama segment of the Alhama de Murcia fault (AMF) in an on-fault location. We identified four Earthquake Archaeological Effects (EAE; Figure 5) that support the occurrence of a palaeoseismic event around 1,550 $\mathrm{BC}$ (or soon after). Two of them are primary EAE (surface rupture and uplift) and the other two are secondary (ground fractures and broken wall-boulders). The latter are reported for the first time in this study, although they have equivalents in the EAE classification of Rodríguez-Pascua et al. (2011). The structural analysis of fracture orientations reveals two main fracture orientations (NE-SW and NW-SE) consistent with the left-lateral kinematics of the AMF zone in the area. The coinciding 
orientations lend support to the coseismic origin of the fractures. The main fracture produces a left lateral displacement $(18 \mathrm{~cm})$ of one of the walls and an apparent differential uplift of 5-8 cm.

Numerical analysis of the data indicates that the recorded deformation is consistent with a $6.4 \pm 0.1 \mathrm{Mw}$ palaeoseismic event of intensity IX ESI-07 in the fault zone. The estimated net lateral slip-rates range between $0.024 \mathrm{~mm} / \mathrm{yr}$ and $0.039 \mathrm{~mm} / \mathrm{yr}$ and are reported for the first time in this fault segment. It is therefore possible to relate the palaeoseismic event to the abandonment of the site in 1,550 cal. BC (Delgado-Raack et al., 2014). This date matches 1) the tectonically induced environmental changes that triggered a large depopulation of the zone during the Late Bronze Age (Calmel-Ávila, 2002; Silva et al., 2008), and 2) the age of one earthquake (1,760 - 830 cal. BC; Masana et al., 2004).

This work affords the first compelling evidence in the Iberian Peninsula of surface rupture recorded by means of archaeoseismological analysis, and provides numerical data on the seismic potential of the analysed segment (Totana - Alhama) of the AMF, previously only characterised by theoretical approaches. An interdisciplinary analysis (archaeology, geology and seismology) of an ancient "lost" earthquake from the Bronze Age has enabled us to make a significant contribution to the historical seismic catalogue.

\footnotetext{
Acknowledgements: This research was funded by SHAKE CGL2011-30005-C02-02 and QTECTBETICA CGL2012-37581-C02-01 projects and supported by CSD2006-0004 "Topo-Iberia" (Consolider-Ingenio 2010). We are indebted to the entire team of La Bastida Project (directors: Vicente Lull, Rafael Micó, Cristina Rihuete-Herrada, Roberto Risch) for all the information supplied. La Bastida
} 
1

2

3

4

5

6

7

8

9

10

11

12

13

14

15

16

17

18

19

20

21

22

23

24

25

26

27

28

29

30

31

32

33

34

35

36

37

38

39

40

41

42

43

44

45

46

47

48

49

50

51

52

53

54

55

56

57

58

59

60

is supported by the projects: HUM2006-04610, HAR2011-25280, TSI-070100-2008-133 and 2009SGR778. Grateful thanks are due to Mari Hernández, Antonio Caño, Nil Domínguez and Cèsar Ferrater, as well as to Klaus Reicherter and an anonymous reviewer for their comments improving the original mansucript. 


\title{
References
}

\begin{abstract}
Alonso-Zarza, A.M., Silva, P.G., Goy, J.L. \& Zazo, C. (1998) Fan-surface dynamics, plant-activity and calcrete development: Interactions during ultimate phases of fan evolution in the semiarid SE Spain (Murcia). Geomorphology, 24, 147-167.
\end{abstract}

Calmel-Avila, M. (2002). The Librilla "rambla" an example of morphogenetic crisis in the Holocene (Murcia, SE Spain). Quaternary International, 93-94, 101-108.

Calmel-Avila, M., Silva, P.G., Bardají, T., Goy, J.L. \& Zazo, C. (2009). Drainage system inversion in the Guadalentín Depression during the Late Pleistocene - Holocene (Murcia, Spain). In: Romero C. et al. (Eds.), Advances in Studies on Desertification. Serv Pub. Univ. Murcia, Spain.

Colas, A.S., Morel, J.C. \& Garnier, D. (2013). Assessing the two-dimensional behaviour of drystone retaining walls by full-scale experiments and yield design simulation. Géotechnique, 63 (2), 107-117.

Delgado-Raack, S., Lull, V., Martin, K., Micó, R., Rihuete Herrada, C. \& Risch, R. (2014). Die Silberschmiede von Tira del Lienzo, Totana, Prov. Murcia, im Kontext der El Argar Metallurgie. In: Meller, H., Risch, R. \& Pernicka, E. (eds), Metalle der Macht - Frühes Gold und Silber, 6. Mitteldeutscher Archäologentag vom 17. bis 19. Oktober 2013 in Halle (Saale), 577-591. 
Echeverria, A., Khazaradze, G., Asensio, E., Gárate, J., Dávila, J.M. \& Suriñach, E. (2013). Crustal deformation in eastern Betics from CuaTeNeo GPS network. Tectonophysics, 608, 600-612. DOI: 10.1016/j.tecto.2013.08.020.

Ferrater, M., (2013). Arqueosismología en La Tira del Lienzo (Totana, Murcia). VI Young Researchers in Archaeology Conference. Barcelona, May 2013.

Ferrater, M., Ortuño, M., Masana, M., Silva, P.G., Rodríguez-Pascua, M.A., Booth-Rea, G. \& Azañón, J.M., (2013). Archaeoseismology in a Bronze aged settlement: La Tira del Lienzo (Totana, Spain). In: Grützner, C., Rudersdorf, A., Pérez-López, R. \& Reicherter, K. (eds) 2013. Seismic hazard, critical facilities and slow active faults. Proceedings of the 4th International INQUA meeting on Paleoseismology, Active Tectonics and Archeoseismology (PATA Days), 9-15 October 2013, Aachen, Germany, ISBN: 978-3-00-042796-1

Frontera, T., Concha, A., Blanco, P., Echeverria, A., Goula, X., Arbiol, R., Khazaradze, G., Pérez, F. \& Suriñach, E. (2012). DinSar coseismic deformation of the May 2011 Mw 5.1 Lorca earthquake, (Southern Spain). Solid Earth, 3, 111-119.

González Guerao, J.A. (2005) Prospección arqueológica de urgencia en paraje Tira del Lienzo, Totana. XVI Jornadas de Patrimonio Histórico. Intervenciones en elPatrimonio arquitectónico, arqueológicoy etnográfico de la Región de Murcia, Murcia, 390-391. ISBN 84-7564-318-3 
Grünthal, G. (ed.) (1998). European macroseismic scale, European Seismological Commission, Sub-commission on Engineering Seismology, Working Group Macroseismic scales, Luxembourg, 99 pp.

Instituto Geográfico Nacional, IGN (2012). Servicio de información sísmica, catálogo de terremotos. Instituto Geográfico Nacional. Available in: http://www.01.ign.es/ign/layoutIn/sismoFormularioCatalogo (accessed on January 2012).

Karabacak, V., Yönlü, Ö., Dökü, E., Kıyak, N. G., Altunel, E., Özüdoğru, Ş., Yalçıner, C. Ç. \& Akyüz, H. S. (2013). Analyses of Seismic Deformation at the Kibyra Roman Stadium, Southwest Turkey. Geoarchaeology, 28, 531-543.

López-Comino, J.A., Mancilla, F., Morales J. \& Stich, D. (2012). Rupture directivity of the 2011, Mw 5.2 Lorca earthquake (Spain). Geophysical Research Letters, 39, L03301, DOI: $10.1029 / 2011 G L 050498$.

Lull, V. (1983). La cultura de El Argar. Un modelo para el estudio de las formaciones económico-sociales prehistóricas. Akal, Madrid, 488pp.

Lull, V., Micó, R., Rihuete Herrada C. \& Risch, R. (2011a). El Argar and the Beginning of Class Society in the Western Mediterranean. Sozialarchäologische Perspektiven: Gesellschaftlicher Wandel 5000-1500 v. Chr. Zwischen Atlantik und Kaukasus (S. Hansen, J. Müller Eds). Deutsches Archäologisches Institut, Berlin, 381-414. 
Lull, V., Micó, R., Rihuete Herrada, C. \& Risch, R. (2011b). Proyecto La Bastida: economia, urbanismo y territorio de una capital argàrica. Verdolay, 13, 57-70. ISSN: 1130-9776

Lull, V., Micó, R., Rihuete Herrada, C. \& Risch, R. (2014). The La Bastida fortification: new light and new questions on Early Bronze Age societies in the western Mediterranean. Antiguity, 88, 395-410.

Martínez-Díaz, J.J. (1998). Neotectónica y Tectónica Activa del Sector CentroOccidental de la Región de Murcia y Sur de Almería (Cordillera Bética - España). Ph.D., UCM, Madrid, Spain, 466pp.

Martínez-Díaz, J.J., Masana, E., Hernández-Enrile J.L. \& Santanach, P. (2001). Evidence for coseismic events of recurrent prehistoric deformation along the Alhama de Murcia fault, southestern Spain. Acta Geologica Hispanica, 36 (3-4), 315-327.

Martínez-Díaz, J.J., Masana, E., Hernández-Enrile, J.L. \& Santanach, P. (2003). Effects of repeated paleoearthquakes on the Alhama de Murcia Fault (Betic Cordillera, Spain) on the Quaternary evolution of an alluvial fan system. Annals of Geophysics, 46 (5), $775-791$.

Martínez-Díaz, J.J., Masana, E. \& Ortuño, M. (2012) Active tectonics of the Alhama de Murcia fault, Betic Cordillera, Spain. Journal of Iberian Geology, 38 (1), 170 -181 
Masana, E., Martínez-Díaz, J.J., Hernández-Enrile, J.L. \& Santanach, P. (2004). The Alhama de Murcia Fault (SE Spain), a seismogenic fault in a diffuse plate boundary: Seismotectonic implications for the Ibero-Magrebianregión. Journal of Geophysical research, 109, B01301, DOI:10.1029/2002JB002359.

Michetti, A.M., Esposito, E., Guerreri, L., Porfido, S., Serva, L., Tatevosian, R., Vittori, E., Audemard, F., Azuma, T., Clague, J., Comerci, V., Gürpinar, A., McCalpin, J., Mohammadioun, B., Mörner, N.A., Ota, Y. \& Roghozin, E. (2007). Intensity Scale ESI2007. Mem. Descr. Carta Geologica d'Italia, 74. Servizio Geológico d'Italia Dipartamento Difensa del Suolo. APAT, Roma, Italia, 41pp.

Nur, A. \& Burgess, D. (2008). Apocalypse: Earthquakes, Archaeology and the Wrath of God. Princeton University Press. Princeton and Oxford, 309 pp.

Ortuño, M., Masana, E., García-Meléndez, E., Martínez-Díaz, J.J., Stepancikovà, P., Cunha, P.P., Sohbati, R., Canora, C., Buylaert, J.P. \& Murray, A.S. (2012). An exceptionally long paleoseismic record of a slow-moving fault: the Alhama de Murcia fault (Eastern Betic Shear Zone, Spain). The Geological Society of America Bulletin, 124 (9-10), 1474-1494, DOI: 10.1130/B30558.1.

Rodríguez-Pascua, M.A., Silva, P.G., Garduño-Monroy, V.H., Pérez-López, R., IsradeAlcántara, I., Giner-Robles, J.L., Bischoff, J.L. \& Calvo, J.P. (2010). Ancient earthquakes from archaeoseismic evidence during the Visigothic and Islamic periods in the archaeological site of "Tolmo de Minateda" (SE Spain). In: Sintubin, M., Stewart, 
I.S., Niemi, T.M., \& Altunel, E., (eds.). Ancient Earthquakes, Geological Society of America Special Paper, 471, 171-184.

Rodríguez-Pascua, M.A., Pérez-López, R., Giner-Robles, J.L., Silva, P.G., GarduñoMonroy, V. H. \& Reicherter, K. (2011). A comprehensive classification of earthquake archaeological effects (EAE) in archaeoseismology: application to ancient remains of roman and mesoamericon cultures. Quaternary International, 242, 20-30.

Rodríguez-Pascua, M.A., Abad Casal, L., Pérez-López, R., Gamo Parra, B., Silva, P.G., Garduño-Monroy, V.H., Giner-Robles, J.L., Perucha-Atienza, M.A., Israde-Alcántara, I., Bischoff, J. \& Calvo, J.P. (2013a). Roman, Visigothic and Islamic evidence of earthquakes recorded in the archaeological site of "El Tolmo de Minateda" (Prebetic Zone, southeast of Spain). Cuaternario y Geomorfología, 27 (3-4), 65-72.

Rodríguez-Pascua, M.A.; Silva, P.G.; Pérez-López, R.; Giner-Robles, J.L.; MartínGonzález, F. \& Perucha-Atienza, M.A. (2013b). Preliminary intensity correlation between macroseismic scales (ESI-07 and EMS-98) and Earthquake Archaaeological Effects (EAEs). Proceedings 4th International INQUA Meeting on Paleoseismology, Active Tectonics and Archeoseismology (PATA), 221-224 October 2013, Aachen, Germany.

Senthivel, R., Lourenco, P.G. \& Vasconcelos, G. (2006). Analytical Modeling of Dry Stone Masonry Wall under Monotonic and Reversed Cyclic Loading. Structural Analysis of Historical Constructions, (P.B. Lourenço, P. Roca, C. Modena, S. Agrawal, Eds.), New Delhi, pp. 1005-1012 
Silva, P.G. (1994) Evolución Geodinámica de la Depresión del Guadalentín desde el Mioceno Superior hasta la actualidad: Neotectónica y Geomorfología. Ph.D. UCM, Madrid, Spain. 642pp.

Silva, P.G. (2014).The Guadalentín Tectonic Depression (Betic Cordillera, Murcia). In: Landscapes and Landforms of Spain (F. Gutiérrez and M. Gutiérrez Eds). World Geomorphological Landscapes Series. Springer Science. Dordrecht, Germany. 25$35 \mathrm{pp}$.

Silva, P.G., Harvey, A.M., Zazo, C. \& Goy, J.L. (1992) Geomorphology, depositional style and morphometric relationships of Quaternary alluvial fans in the Guadalentin Depression (Murcia, SE Spain). Z F Geomorphologie, 36, 661-673.

Silva, P.G., Goy, J.L., Somoza, L., Zazo, C. \& Bardají, T. (1993) Landscape response to strike-slip faulting linked to collisional settings: Quaternary tectonics and basin formation in the Eastern Betics, Southeast Spain. Tectonophysics, 224, 289-303.

Silva, P.G., Goy, J.L., Zazo, C. \& Bardají, T. (1997). Paleoseismic indications along "aseismic" fault segments in the Guadalentín Depression (SE Spain). Journal of Geodynamics, 24 (1-4), 105-115.

Silva, P.G., Goy, J.L., Zazo, C. \& Bardají, T. (2003). Fault-generated mountain fronts in southeast Spain: Geomorphologic assessment of tectonic and seismic activity. Geomorphology, 50, 203-225. 
Silva, P.G., Borja, F., Zazo, C., Goy, J.L., Bardají, T., De Luque, L., Lario. J. \& Dabrio, C. (2005). Archaeoseismic record at the ancient Roman City of Baelo Claudia (Cádiz, South Spain). Tectonophysics, 408 (1-4), 129-146

Silva, P.G., Calmel-Avila, M., Bardají, T., Goy, J.L. \& Zazo, C. (2008) Transition from alluvial to fluvial systems in the Guadalentin Depression (SE Spain) during the Holocene: Lorca Fan versus Guadalentín River. Geomorphology, 100, 144-153.

Silva, P.G., Reicherter, K., Grützner, C., Bardají, T., Lario. J., Goy, J.L., Zazo, C. \& Becker-Heidmann, P. (2009). Surface and subsurface palaeoseismic records at the ancient Roman city of Baelo Claudia and the Bolonia Bay area, Cádiz (south Spain). Geological Sicety, London, Spetial Publicacions, 316, 93-121.

Silva, P.G. \& Rodríguez-Pascua, M.A. Eds (2014). Catálogo de los Efectos Geológicos de los Terremotos en España. Serie Riesgos Geológicos/Geotécnia, 4. Instituto Geológico y Minero de España (IGME), Madrid, 358 pp.

Stirling, M.W., Rhoades, D.A. \& Berryman, K. (2002). Comparison of earthquake scaling relations derived from data of the instrumental and preinstrumental era. Bulletin of the seismological Society of America, 92 (2), 812-830.

Stirling, M., Goded, T., Berryman, K. \& Litchfield, N. (2013). Selection of earthquake scaling relationships for seismic-hazard analysis. Bulletin of the seismological Society of America, 103 (6), 2993-3011. 
Wells, K. \& Coppersmith, D.L. (1994). New Empirical Relationships among Magnitude, Rupture Length, Rupture Width, Rupture Area, and Surface Displacement. Bulletin of the seismological Society of America, 84, 974-1002.

Wesnousky, S.G. (2008). Displacement and geometrical characteristics of earthquake Surface ruptures: Issues and implications for seismic-hazard analysis and the process of earthquake rupture. Bulletin of the seismological Society of America, 98 (4), 16091632. 
Table 1. Theoretical moment magnitude for different fault segments and combinations of fault segments according to their length.

Figure 1. Tira del Lienzo site and Alhama de Murcia fault zone. Dashed lines correspond to the El Romeral fault that is not visible in outcrop. The locations of other sites/localities cited in the text are also highlighted.

Figure 2: La Tira del Lienzo. A) geological setting of La Tira del Lienzo (legend: N1 (gypsum), N2 (shale), N3 (conglomerate and shale), Neogene basement; Q1-Q2-2, Quaternary alluvial fans younger to older; FI0-FI-2, Quaternary fluvial infill younger to older; AMF fault traces in red, dashed (inferred traces); B) Geological interpretation of the pressure-ridge where La Tira del Lienzo is located.

Figure 3: Planimetric map of the site provided by the archaeological group of the Universitat Autònoma de Barcelona (La Bastida Project). Location of all the Earthquake Archaeological Effects (EAEs). Numbers correspond to the fractures in Figure 4. Houses and walls where earthquake effects were identified are highlighted.

Figure 4: Photographs and structural analysis of ground fractures and fractures on broken wall-boulders (numbers correspond to the position of the fractures in the map in Figure 3). Structural analysis includes stereographic projections and rose diagrams. In the Alhama de Murcia fault structural analysis fault planes and striae are shown. Some photographs were taken after repair work was done by the La Bastida project for conservation of the site. 
Figure 5: EAEs identified at Tira del Lienzo and their equivalence in the RodríguezPascua et al. (2011) EAEs classification. New EAEs proposed in this work are highlighted.

Figure 6: Detail of the offset wall (W46) in relationship with the other EAEs (broken boulders, ground fractures and ground deformation); same legend as in figure 3. A, B and $\mathrm{C}$ are images of the W46 wall from different angles.

Figure 7: Proposed time span for palaeoseismic, ancient (this study) and historical seismic events in the central sector of the Alhama de Murcia fault (AMF). Information: Fault-segment (length km; Mw theoretical (Martínez-Díaz et al., 2012)); references for the proposed events. El Romeral is not considered in Martínez-Díaz et al., 2012, but we have calculated its theoretical magnitude based on the methodology followed by these authors (magnitude versus area with width of $12 \mathrm{~km}$ ). 


\begin{tabular}{|l|c|c|}
\hline Segment & $\begin{array}{l}\text { Length } \\
(\mathbf{e}=\mathbf{1} \mathbf{~ k m})\end{array}$ & $\begin{array}{c}\text { Mw theoretical (Magnitude vs Length; Wells \& } \\
\text { Coppersmith, 1994) }\end{array}$ \\
\hline $\begin{array}{l}\text { Lorca-Totana }+ \\
\text { Totana-Alhama }\end{array}$ & $34 \mathrm{~km}$ & $6.9 \pm 0.2$ \\
\hline $\begin{array}{l}\text { El Romeral } \\
\text { (blind fault) }\end{array}$ & $22 \mathrm{~km}$ & $6.6 \pm 0.2$ \\
\hline $\begin{array}{l}\text { Totana-Alhama }+ \\
\text { El Romeral }\end{array}$ & $33 \mathrm{~km}$ & $6.9 \pm 0.2$ \\
\hline Lorca-Romeral & $56 \mathrm{~km}$ & $7.1 \pm 0.2$ \\
\hline
\end{tabular}




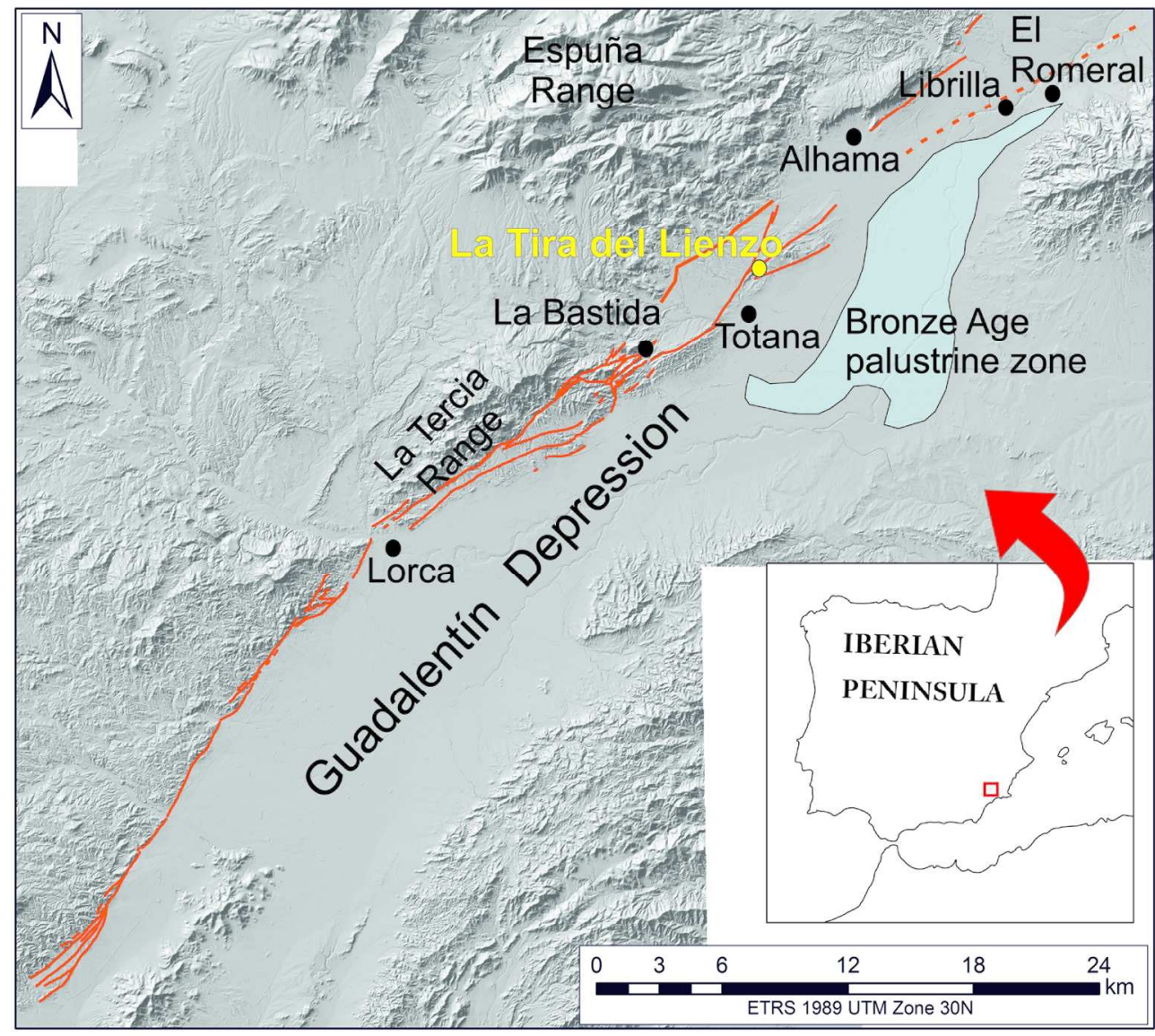

$186 \times 167 \mathrm{~mm}(300 \times 300 \mathrm{DPI})$ 

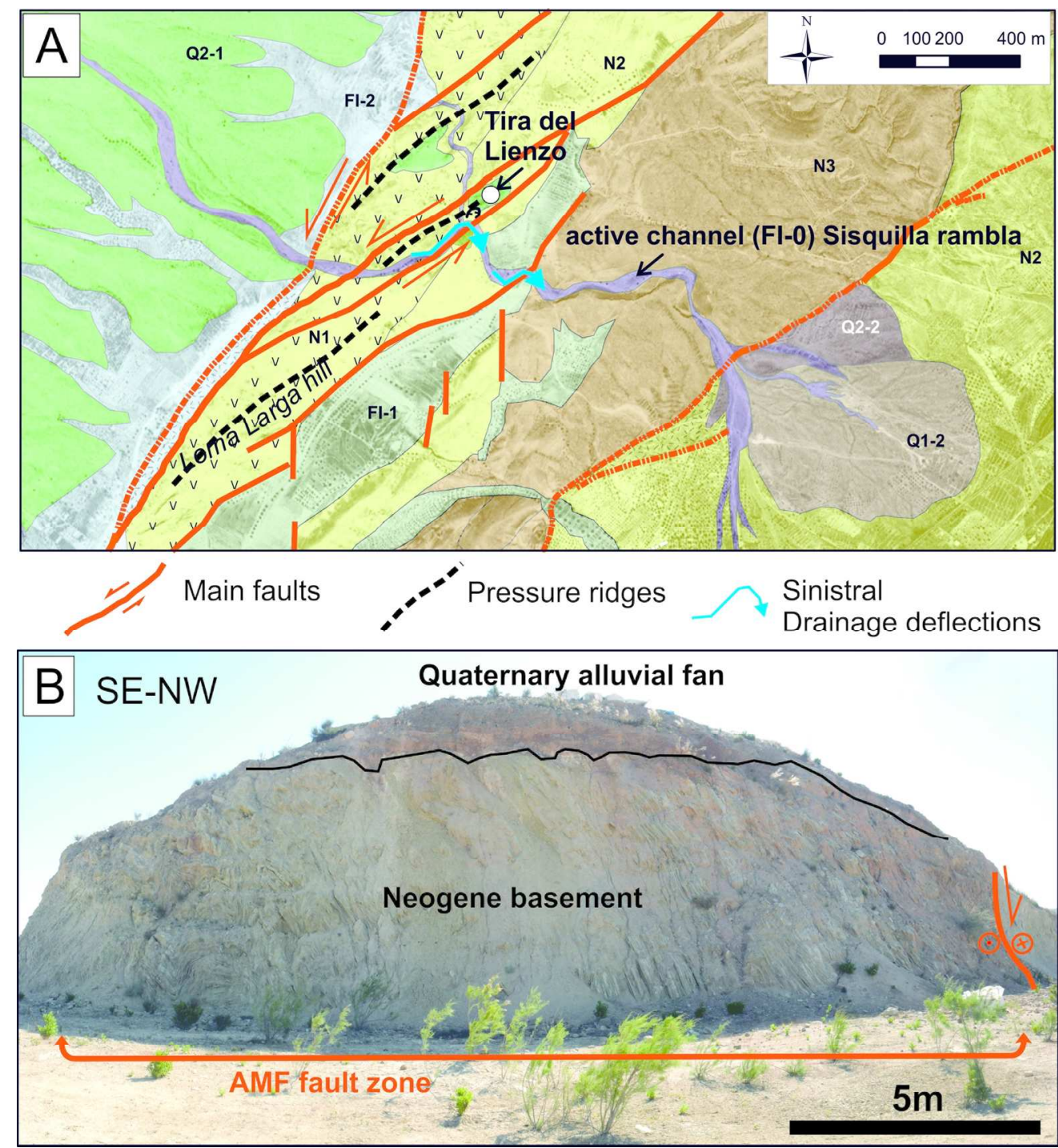

$198 \times 216 \mathrm{~mm}(300 \times 300 \mathrm{DPI})$ 


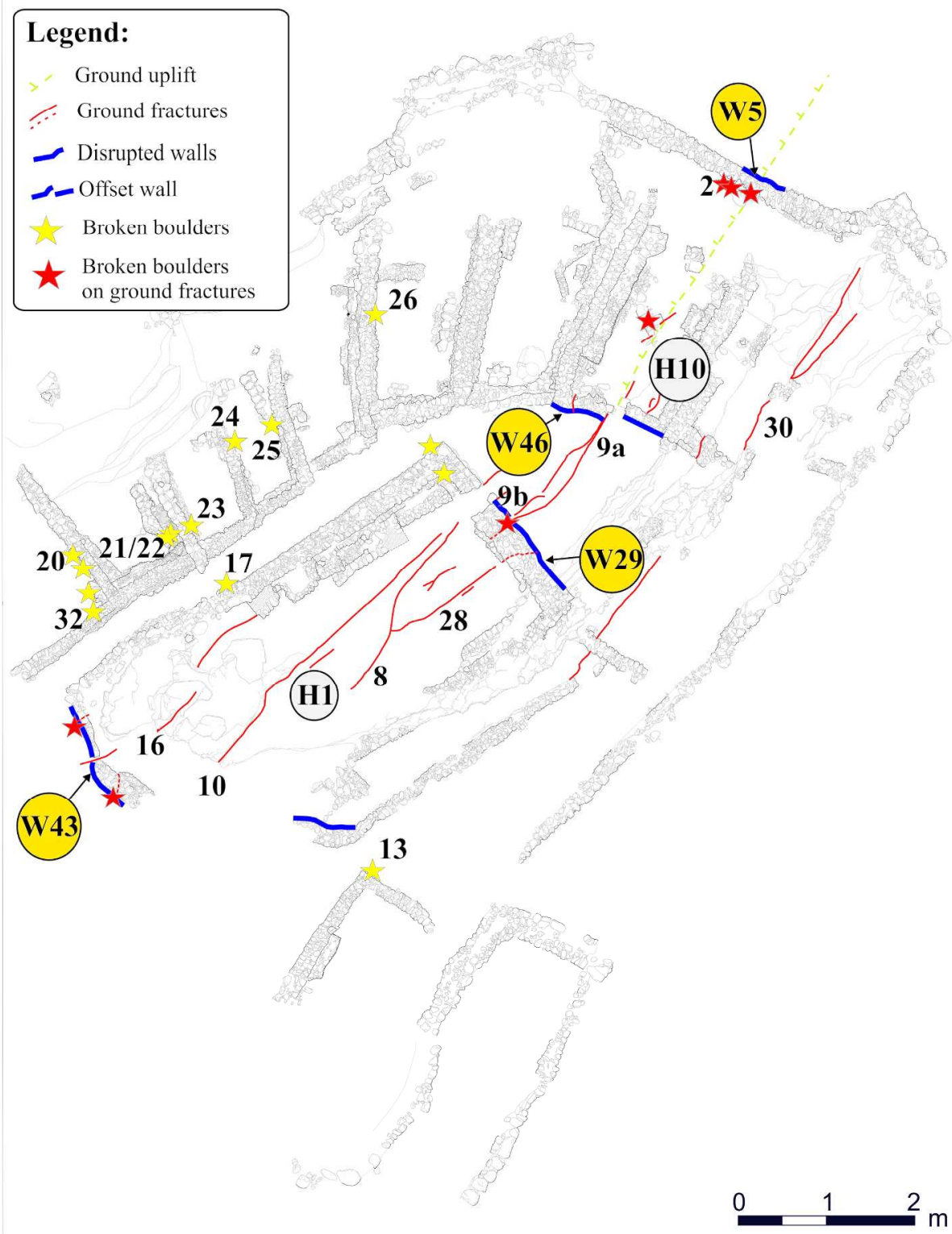

$360 \times 464 \mathrm{~mm}(300 \times 300 \mathrm{DPI})$ 

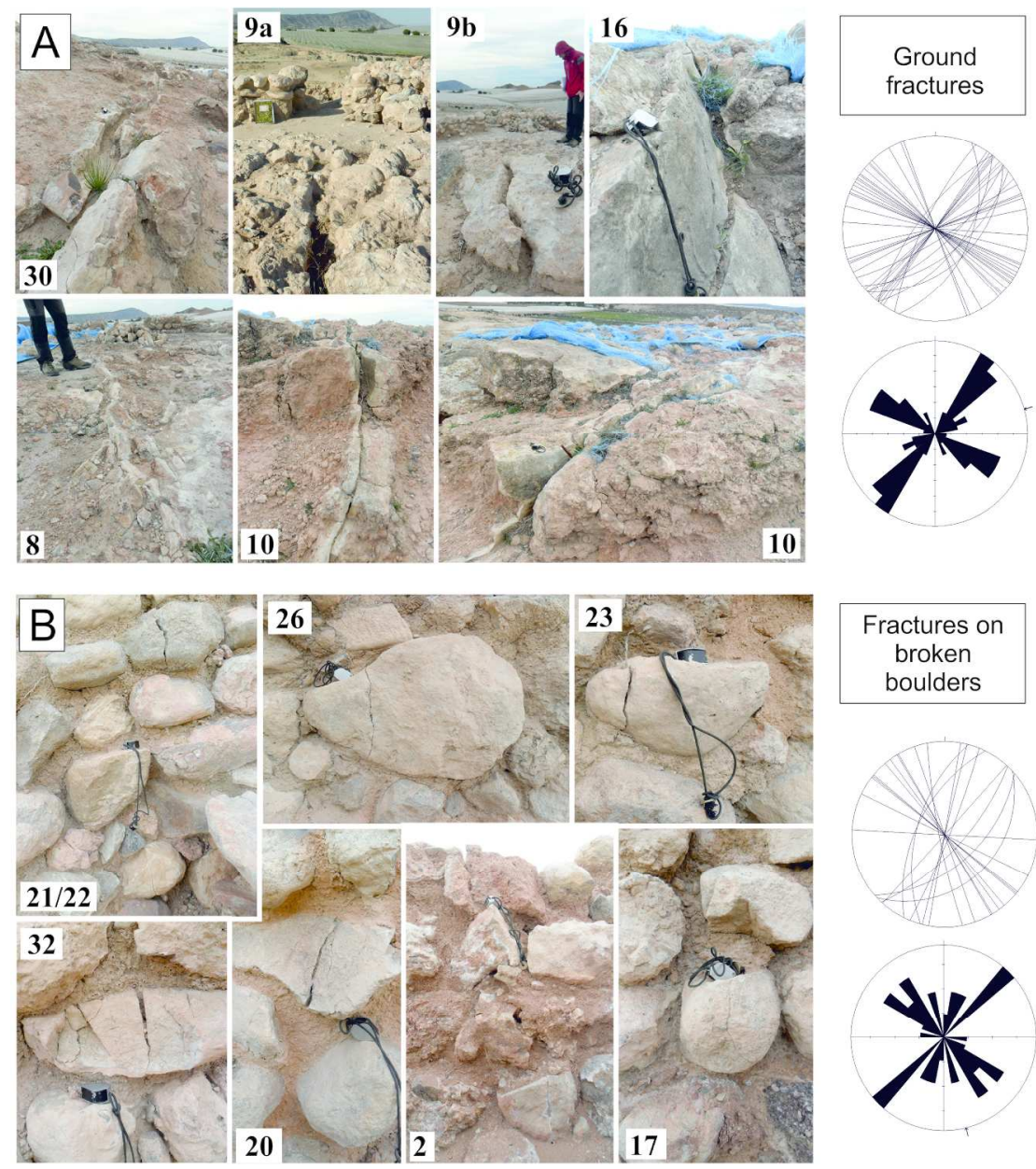
Fractures on broken boulders

Alhama de Murcia Fault

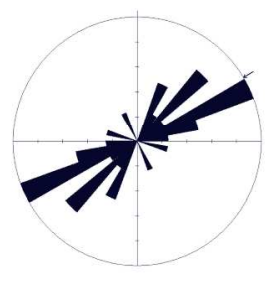

$285 \times 402 \mathrm{~mm}(300 \times 300$ DPI $)$ 


\section{$93 \times 62 \mathrm{~mm}(300 \times 300$ DPI $)$}




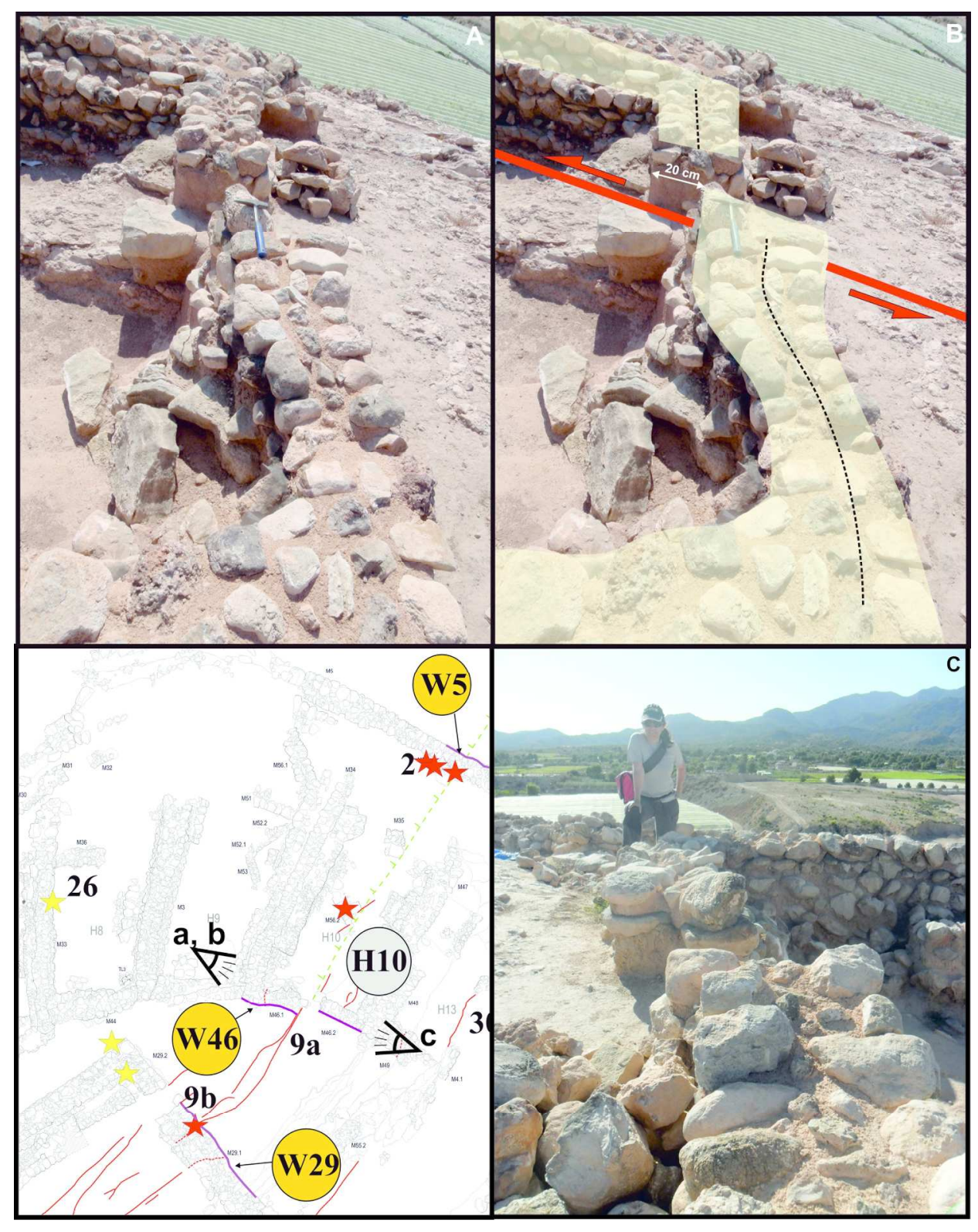

$248 \times 313 \mathrm{~mm}(300 \times 300$ DPI $)$ 
Lorca - Totana (23 km; 6.1 - 7.0); Masana et al., 2004

$2130-830 \mathrm{BC}(\mathrm{Mw}=6.5-7.0)$

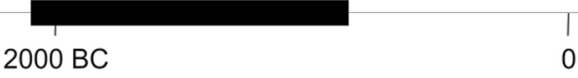

Shortly before $1650 \mathrm{AD}(\mathrm{Mw}=6.5-7.0)$

0

Present day

Totana - Alhama (11 km; 5.9 - 6.5); this work

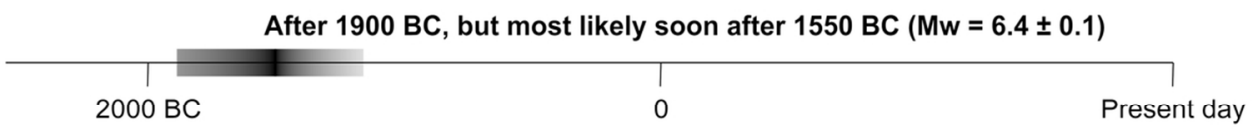

El Romeral (22 km; 6.3 - 6.6); Calmel-Ávila, 2002

After $1885 \mathrm{BC}$

\begin{tabular}{c|cc}
\hline P & & \\
\hline $2000 \mathrm{BC}$ & 0 & Present day
\end{tabular}

$104 \times 53 \mathrm{~mm}(300 \times 300 \mathrm{DPI})$ 